\title{
PEDCARE: validation of a mobile application on diabetic foot self-care
}

\author{
PEDCARE: validação de um aplicativo móvel sobre o autocuidado com o pé diabético \\ PEDCARE: validación de una aplicación móvil sobre el autocuidado del pie diabético
}

\section{Antonio Dean Barbosa Marques' ORCID: 0000-0001-8969-1546}

Thereza Maria Magalhães Moreira" ORCID: 0000-0003-1424-0649

Rhanna Emanuela Fontenele Lima de Carvalho' ORCID: 0000-0002-3406-9685

Edna Maria Camelo Chaves' ORCID: 0000-0001-9658-0377

Shérida Karanini Paz de Oliveira' ORCID: 0000-0003-3902-8046

Gilvan Ferreira Felipe" ORCID: 0000-0003-0674-4396

Jarbas Aryel Nunes da Silveira"l ORCID: 0000-0003-2590-9520

'Universidade Estadual do Ceará. Fortaleza, Ceará, Brazil. "Universidade da Integração Internacional da Lusofonia Afro-brasileira. Redenção, Ceará, Brazil I"Universidade Federal do Ceará. Fortaleza, Ceará, Brazil.

How to cite this article: Marques ADB, Moreira TMM, Carvalho REFL, Chaves EMC, Oliveira SKP, Felipe GF, et al. PEDCARE: validation of a mobile application on diabetic foot self-care. Rev Bras Enferm. 2021;74(Suppl 5):e20200856. https://doi.org/10.1590/0034-7167-2020-0856

\section{Corresponding author:}

Antonio Dean Barbosa Marques E-mail: antonio-dean@hotmail.com

EDITOR IN CHIEF: Antonio José de Almeida Filho ASSOCIATE EDITOR: Fátima Helena Espírito Santo

\section{ABSTRACT}

Objective: to describe the process of validating a multimedia application on a mobile platform to promote foot care for people with diabetes. Method: a technological production and methodological type study. Content and appearance were validated by 39 judges ( 29 nursing judges and ten information and communication technology judges and 15 people from the target audience). Results: nursing judges made it possible to validate the material with a total Content Validity Index of 0.95, a non-significant binomial test for most items and Cronbach's alpha of 0.92 , information and communication technology judges with Suitability Assessment of Materials of $99.2 \%$ and the target audience with an agreement index of $98 \%$. Conclusion: the application proved to be valid and reliable for use in clinical practice as an educational technology to promote foot care for people with diabetes.

Descriptors: Diabetes Mellitus; Diabetic Foot; Mobile Applications; Health Education Validation Study.

\section{RESUMO}

Objetivo: descrever o processo de validação de aplicativo multimídia em plataforma móvel para a promoção de cuidado com os pés de pessoas com diabetes. Método: estudo de produção tecnológica, do tipo metodológico. O conteúdo e a aparência foram validados por 39 juízes (29 juízes na área de enfermagem e dez com experiência profissional em tecnologia da informação e comunicação e 15 pessoas do público-alvo). Resultados: os juízes na área de enfermagem possibilitaram a validação do material com Índice de Validade do Conteúdo total de 0,95 , teste binomial não significativo para maioria dos itens e alfa de Cronbach de 0,92, juízes da área de tecnologia da informação e comunicação com Suitability Assessment of Materials de 99,2\% e o público-alvo com Índice de Concordância de $98 \%$. Conclusão: o aplicativo mostrou-se válido e confiável para uso na prática clínica como tecnologia educacional para promoção de cuidados com os pés de pessoas com diabetes.

Descritores: Diabetes Mellitus; Pé Diabético; Aplicativos Móveis; Educação em Saúde; Estudos de Validação.

\section{RESUMEN}

Objetivo: describir el proceso de validación de una aplicación multimedia en una plataforma móvil para promover el cuidado de los pies en personas con diabetes. Método: estudio de producción tecnológica, tipo metodológico. El contenido y apariencia fueron validados por 39 jueces (29 jueces en el campo de la enfermería y diez con experiencia profesional en tecnologías de la información y la comunicación y 15 personas del público objetivo). Resultados: los jueces del área de enfermería permitieron validar el material con un Índice de Validez de Contenido de 0,95 , una prueba binomial no significativa para la mayoría de los ítems y un alfa de Cronbach de 0,92, jueces de tecnología de la información y la comunicación con Suitability Assessment of Materials de 99,2\% y el público objetivo con un Índice de Concordancia de $98 \%$. Conclusión: la aplicación demostró ser válida y confiable para su uso en la práctica clínica como una tecnología educativa para promover el cuidado de los pies en personas con diabetes.

Descriptores: Diabetes Mellitus; Pie Diabético; Aplicaciones Móviles; Educación en Salud Estudio de Validación 


\section{INTRODUCTION}

Diabetes mellitus (DM) has notoriety in global health, regardless of its degree of development, with a worldwide prevalence of $8.5 \%$, and estimates suggest that the number of people affected will increase from 422 million to 642 million worldwide by $2040^{(1)}$. With exponential increase, it has surpassed expectations and shows itself as a trend, due to the increase in the average age of the community, hereditary antecedents, unhealthy eating habits, sedentary lifestyle and increased obesity, according to the growth of urbanization ${ }^{(2)}$.

In Brazil, the prevalence of DM is $7.5 \%$, ranking $4^{\text {th }}$ among the countries with the highest prevalence of adults with DM and $5^{\text {th }}$ in terms of health expenses, together with the 14.3 million people with the disease ${ }^{(3)}$. Many of its associated factors are identified as preventable, such as functional health literacy ${ }^{(4)}$. Low diabetes literacy is the greatest barrier to incorporating effective preventive strategies ${ }^{(5-6)}$, especially before disease complications, such as diabetic foot.

It is estimated that $20 \%$ of people with diabetes may have dysfunctions in their feet, $5-10 \%$ of foot ulcers and up to $3 \%$ develop amputations. Promotion and prevention strategies have the potential to prevent $44 \%$ to $85 \%$ of amputations ${ }^{(7)}$. In this perspective, to improve the perception about the care and preventive measures of complications of the diabetic foot and, consequently, adherence to the guidelines, the educational intervention is healthy favoring behavior change.

To mediate teaching and learning processes, nurses can use various educational technologies with a view to promoting health. Among them, mobile health or mHealth, which is based on medical or public health practice mediated by mobile devices, such as cell phones ${ }^{(8)}$.

MHealth applications (APP) have been used in a variety of contexts, such as oncology, acute, chronic and metabolic diseases, Primary Health Care, geriatrics, pediatrics, critical care, mental health, nutrition, physical activity, drug and alcohol use, among others ${ }^{(9)}$. Considering the diabetic foot as one of the main complications of people with DM and because it is a condition that involves exhaustive monitoring and the challenge of raising awareness of customers about the need for changes in behavior using educational technologies, especially mHealth, like creating a multimedia on a mobile platform, it can be effective in controlling DM.

Building and validating an APP based on adult people's real needs with diabetic foot may be able to foster foot care promotion for people with DM. In the long run, the APP will be able to reduce healthcare costs with amputations and prevent complications.

\section{OBJECTIVE}

To describe the process of validating a multimedia application on a mobile platform to promote foot care for people with diabetes.

\section{METHODS}

\section{Ethical aspects}

This study was approved by the Research Ethics Committee (CEP) of Universidade Estadual do Ceará (UECE), as established by the Brazilian National Health Council (CNS - Conselho Nacional de Saúde), through Resolution 466/12, which refers to research involving human beings.

\section{Design, study location, and period}

This is a methodological study ${ }^{(10)}$, clipping of a doctoral thesis in nursing ${ }^{(11)}$, focusing on the process of validating the content, appearance and suitability of a technology produced by judges via online and target audience at an Integrated Center for Diabetes and Hypertension (CIDH - Centro Integrado de Diabetes e Hipertensão) in Fortaleza, Ceará, from February to April 2018. Equator's SQUIRE 2.0 instrument was used to guide the methodology.

\section{Population and sample; inclusion and exclusion criteria}

All experts were divided into three groups: 1) content judges composed of researchers/professors with experience in the area of DM with an emphasis on diabetic foot, educational technologies and/or validation of instruments and nurses with experience in clinical care for people with foot diabetic; 2) ten judges with professional experience in ICT (Information and Communication Technology) (design or marketing); 3) target audience (people with DM and foot at risk) ${ }^{(12)}$. The sample size for judges and target audience was delimited by convenience.

Different strategies were used to recruit judges. Through a system of virtual curricula, an invitation was sent by the main researcher of the study or indication of participating judges.

Those in the nursing field were approached through a platform of virtual curricula that scored at least 5 points: academic work at master's and doctoral level (1 point for each); author of at least one published article (1 point per article); participation of groups and / or research (1 point); participation in evaluation boards at undergraduate and graduate level lato sensu and stricto sensu (1 point for each participation); teach discipline (1 point per year); professional assistance experience in DM ( 0.5 points per year); guide work at the undergraduate and graduate level lato sensu and stricto sensu ( 0.5 per work).

Nursing judges and ICT judges with experience in clinical practice $(0.5$ per year), practical experience with people with diabetic foot (1 point per year), teaching experience in the area of interest ( 0.5 point per year), specialization in the area of interest $(1$ point), who participated in events in the area of interest $(0.5$ per event), presented work in events in the area of interest ( 0.5 per work) and who work at $\mathrm{CIDH}$ (1 point) were included. Establishing a cut-off score of at least 5 points, with ICT judges replacing the area of interest with ICT and/or advertising and marketing.

For the target audience, whoever had DM 2 was chosen, was accompanied by the $\mathrm{CIDH}$, aged $\geq 18$ years and physical and emotional conditions subjectively defined by the researcher to participate in the study. Those who had difficulty in usability by the mobile device (tablet or smartphone) chosen by this one were excluded.

\section{Study protocol}

Content judges approached by accessing and searching the Lattes Platform as follows: after accessing the "Lattes Platform" 
website, in the "Lattes Curriculum" window, the "Search" option was chosen in the "Search Lattes Curriculum" window. The first step was to choose the search mode, clicking on the "Subject" box and in the reserved space, "Diabetic foot" and "Health educational technologies" were written separately.

An invitation letter was sent to the two groups of judges via email (to participate in the validation process). The letter was about aspects of the study, such as objectives. Those who agreed to participate, were asked to send an email to the exclusive email address for the validation process, expressing their agreement and the email address they access most often. Soon after, the first round of the assessment process began. The assessment instrument, the ICF and the file in PDF format with the prototype screens that simulated usability were made available through Google Docs.

Another way adopted for nursing and ICT judges was through an invitation by the main author of the study or through the snowball sampling technique, as they have professional experience in clinical nursing care for people with diabetic foot or foot in risk or in the ICT area.

The assessment instrument for nursing judges was composed of two parts: a) academic and professional data; b) content assessment by domains (objectives and content, structure and functionality and relevance). For validation of ICT judges, the instrument Suitability Assessment of Materials (SAM) was used ${ }^{(13)}$.

A 15-day period to return the assessment instruments was granted, this period being extended for an equal period with the making of a new contact with further clarifications; when there was no return of the instrument within the pre-established period, a judge was excluded.

Only after the adjustments suggested by the groups of judges (content judges and ICT judges) did the target audience assess the prototype.

In April 2018, the APP prototype was validated by the public at $\mathrm{CIDH}$. Participants were recruited through previous contact, personally, during the consultation and/or meetings of groups promoted at the institution where the research was conducted. These were informed about the conduct of the research, and those who showed interest were asked to sign the ICF. Then, people watched the tutorial presentation and explanations concerning the prototype. Subsequently, it was intended for the handling of the APP, with the role of the researcher as a mediator of use. The established time for handling was 25 minutes. The target audience analyzed the structure, the graphic part with regard to calligraphy and handwriting, aspect and stimulus and mood of the APP.

\section{Analysis of results, and statistics}

Aiming at content validity objectivity, Content Validity Index (CVI) was calculated based on the average number of responses " 3 " and "4" selected by experts. The CVI of items (CVli) greater than or equal to 0.78 and an average total CVI of $>0.90$ was considered excellent ${ }^{(12)}$.

For item analysis and their adequacy to the psychometric criteria, the arithmetic mean of each criterion was calculated by the sum of the indicator scores, divided by the number of experts. The exact test of binomial distribution indicated for small samples was carried out, with a significance level of $p>0.05$ and a proportion of 0.95 of agreement to estimate the CVI's statistical reliability. For internal consistency analysis, Cronbach's alpha was calculated, a widely used diagnostic measure, whose values should be between 0.70 and 0.95 , since values less than 0.70 indicate a low correlation between items and greater than 0.95 a very strong correlation, suggesting redundancy between items $\mathrm{s}^{(14)}$.

The total adequacy score calculation was made from the sum of the scores obtained, divided by the total scores and multiplied by 100 , to transform into a percentage. In all situations, the interpretation of the SAM estimate percentage is as follows: 70$100 \%$ (superior material), $40-69 \%$ (adequate material) or $0-39 \%$ (inadequate material). Items with an Agreement Index less than or equal to $39 \%$ (inappropriate material) are considered worthy of change $\mathrm{e}^{(13)}$.

\section{RESULTS}

The built APP was called PedCare. Its development took place in a hybrid manner, i.e., it uses HTML, CSS and JavaScript languages to be compiled for Android and iOS platforms. Using languages that are directed to the web, which meets all the functional requirements of a mobile platform.

We opted to use organic colors (natural and bright tones), which refer to care and safety, but in a technological way, keeping white or gray close. The logo has a very simple design, to facilitate assimilation, but a slight movement and shading, to look like a 3D, making a more dynamic design. The font used was Gilroy, sans serif, clean and easy to read. Using light and bold served to break the word, which is written together, following a movement of online culture. Finally, the APP's identity was designed to be fluid and organic, bringing lightness and balance. This effect is achieved with the elements that move slowly.

PedCare consists of a home screen with a menu containing 11 options: why is foot care important? (05 screens); daily care (05 screens); healthy feet habits (01 screen); toenails (01 screen); shoes (04 screens); signs and symptoms (03 screens); complications (01 screen); exercises to improve circulation (08 screens); foot at risk classification (05 screens); visiting the nurse and/or physician (01 screen); quiz (11 screens). In the settings, patients can access the daily foot care alarm and consultation with the nurse and/or physician (Figure 1).

Content validation was performed by 29 nurses, aged between 26 and 53 years, with an average of $36.6 \pm 7.1$ years from Ceará (23; 79.3\%), Piauí (02; 6.9\%), Pará $(01 ; 3.4 \%)$, Rio Grande do Norte $(01 ; 3.4 \%)$, São Paulo $(01 ; 3.4 \%)$ and Paraná $(01 ; 3.4 \%)$ States. The duration of professional activities ranged from two to 30 years (11.5 \pm 6.7 years), where $27(93.1 \%)$ had experience in clinical care for people with DM and 10 (34.5\%) had related publications to educational technologies.

The APP prototype's total CVI was 0.95. The items used for CVI were divided into three categories: 1) objectives and content, with six items $(\mathrm{CVI}=0.95) ; 2)$ structure and functionality, with ten items $(C V I=0.91) ; 3)$ relevance, with four items $(C V I=0.99)$. In the binomial test, there was a significant disagreement among judges on items $11(p=0.000), 12(p=0.000), 13(p=0.000)$ and 14 $(p=0.014)$ (Table 1). Cronbach's alpha was 0.92 . 


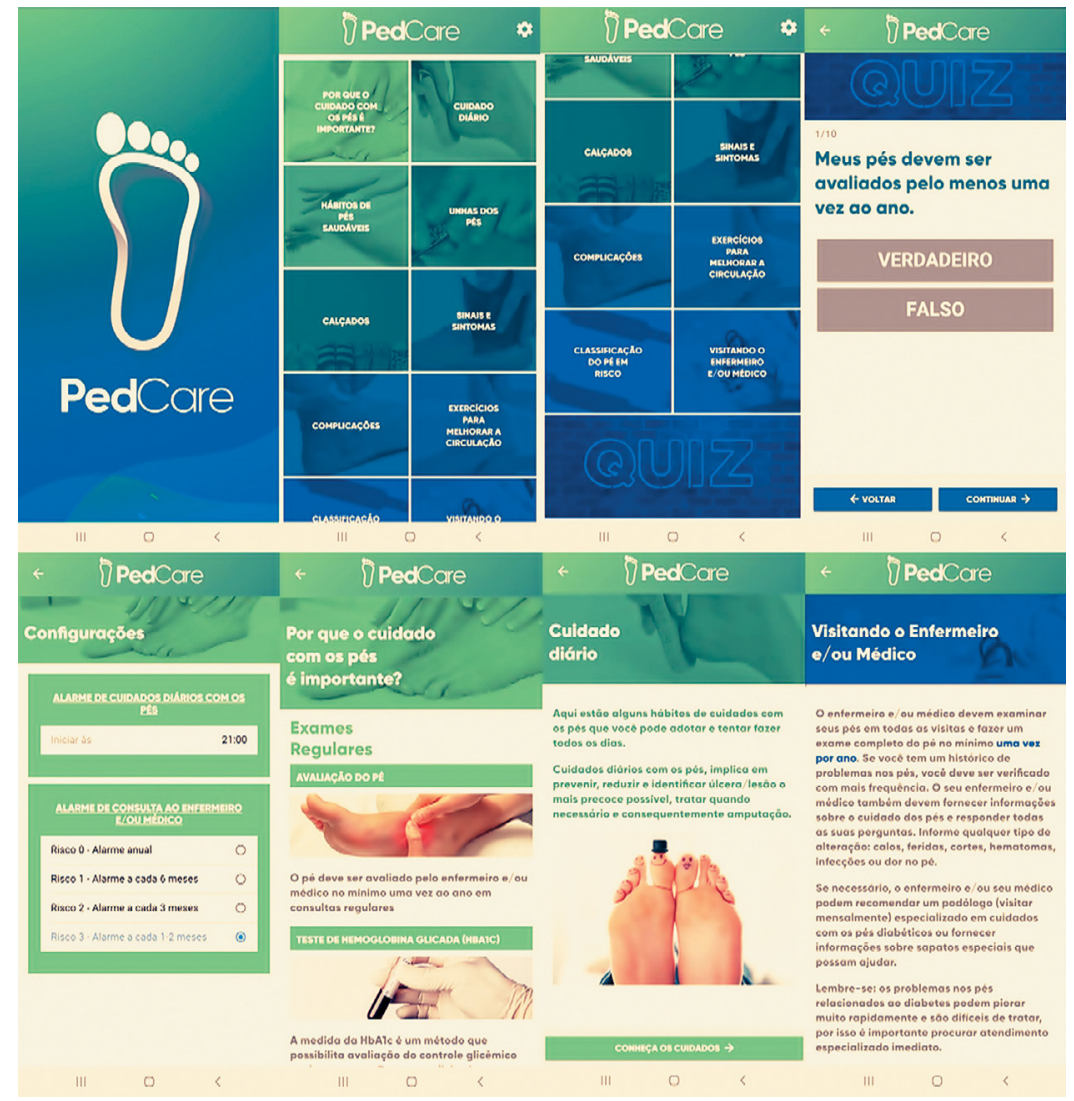

Caption: por que o cuidado com os pés é importante? - why is foot care important?; cuidado diário - daily care hábitos de pés saudáveis - healthy foot habits; unhas dos pés - toenails; calçados - footwear; sinais e sintomas - sign and symptoms; complicações - complications; exercícios para melhorar a circulação - exercises to improve circulation; classificação do pé em risco - foot at risk classification; visitando o enfermeiro e/ou médico - visiting the nurse and/or physician; configurações - settings; alarme de cuidados diários com os pés - daily foot care alarm; iniciar às - begin at; alarme de consulta ao enfermeiro e/ou médico - nurse and/or physician consultation alarm; risco - risk; alarme anual - annua alarm; alarme a cada 6 meses - alarm every 6 months; alarme a cada 3 meses - alarm every 3 months; alarme a cada 1-2 meses - alarm every 1-2 months; exames regulares - regular checkups; avaliação do pé - foot assessment; 0 pé deve ser avaliado pelo enfermeiro e/ou médico no mínimo uma vez ao ano em consultas regulares - the foot must be assessed by the nurse and/or physician at least once a year in regular consultations; teste de hemoglobina glicada (HBATC) - glycated hemoglobin test (HBATC); a medida do HBATC é um método que possibilita avaliação do controle glicêmico - HBATC measurement is a method that allows assessment of glycemic control; aqui estão alguns hábitos de cuidados com os pés que você pode adotar e tentar fazer todos os dias - here are some foot care habits that you can adopt and try to do every day; cuidados diários com os pés, implica em prevenir, reduzir e identificar úlcera/lesão e mais precoce possível, tratar quando necessário e consequentemente amputações - daily foot care involves preventing, reducing and identifying ulcers/injuries and, as early as possible, treating when necessary and consequently amputations; conheço os cuidados - I know the care; meus pés devem ser avaliados pelo menos uma vez ao ano - my feet must be assessed at least once a year; verdadeiro - true; falso - false; voltar - back; continuar - continue; o enfermeiro e/ou médico devem examinar seus pés em todas as visitas e fazer um exame completo do pé no mínimo uma vez por ano. Se você tem um histórico de problemas nos pés, você deve ser verificado com mais frequência. O seu enfermeiro e/ou médico também devem fornecer informações sobre o cuidado dos pés e responder todas as suas perguntas. Informe qualquer tipo de alteração: calos, feridas, cortes, hematomas, infeções ou dor no pé; se necessário, o enfermeiro e/ou seu médico podem recomendar um podólogo (visitar mensalmente) especializado em cuidados com os pés diabéticos ou fornecer informações sobre sapatos especiais que possam ajudar - the nurse and/or physician should examine your feet at all visits and have a complete examination of your foot at least once a year. If you have a history of foot problems, you should be checked more often. Your nurse and/or physician should also provide information about foot care and answer all your questions. Report any type of change, such as calluses, wounds, cuts, bruises, infections or pain in the foot; if necessary, the nurse and/or your physician can recommend a podiatrist (visit monthly) specializing in diabetic foot care or provide information about special shoes that can help; lembre-se: os problemas nos pés relacionados ao diabetes podem piorar muito rapidamente e são difíceis de tratar, por isso é importante procurar atendimento especializado imediato - remember: diabetes-related foot problems can get worse very quickly and are difficult to treat, so it is important to seek immediate specialist care.

Figure 1 - PedCare application screens, Fortaleza, Ceará, Brazil, 2018

Content judges recommended spelling and grammatical correction, additions and minimization of information, language standardization, among others. It is noteworthy that the suggestions deemed pertinent were accepted.

Ten ICT judges participated in appearance validation. There was a predominance of males (90\%), with a mean age of $35.1 \pm$ 8.13 years. Most (70\%) had a degree in information technology (information system and computer science), with an average of 8.7 years of training, with $70 \%$ working in the field of information technology as experts (40\%).

The judges assessed the APP prototype in terms of: 1) content; 2) literacy requirements; 3) illustrations; 4) layout and presentation; 5) encouragement/motivation of learning; 6 ) cultural adequacy. It was observed that no expert with experience in ICT assessed as inappropriate (Table 2).

Considering the assessment carried out by the technical judges, the average obtained from the total score was $39.6 \pm 3.3$ points, with a minimum value of 35 and a maximum of 44 , being proved by all ICT judges. The total percentage of the APP was $90.0 \%$.

With the assessments carried out by nursing and ICT judges (professors and assistants), validation was carried out with the target audience. Fifteen patients with DM participated in the validation process. Most $(09 ; 60 \%)$ were women, with an average age of 50.8 years; six $(40 \%)$ were single; six $(40 \%)$ were married; two (13.3\%) were divorced; one $(6.7 \%)$ was widowed; nine $(60 \%)$ had completed elementary school and had an average of 11.2 years of diagnosis of the disease. Most $(09 ; 60 \%)$ used mixed therapy.

The target audience assessed the prototype based on: 1) organization; 2) writing style; 3) appearance; 4) motivation (Table 3). It was observed that all items assessed had positive agreement above $75 \%$ and nine items had positive agreement by all participants, reaching $100 \%$, with a $98 \%$ Agreement Index.

In addition to answering the instrument's objective questions, participants made comments regarding the APP prototype. In general, the APP was considered useful, easy to understand and handle.

\section{DISCUSSION}

The APP developed was intended to foster and educate patients with DM in practice of self-care and health promotion. Diabetes self-management tasks can be quite challenging due to lack of training, difficulties in sustaining lifestyle changes, and limited access to specialized health care. Health education is recognized as an empowerment resource, effective in training for self-care, in which patients are the authors in controlling the condition ${ }^{(15)}$. Mobile technologies are built to strengthen guidance to family members and patients, allowing acquisition of knowledge, skills and responsibility to effect changes in attitudes and increase decision-making power ${ }^{(16)}$. 
Table 1 - Content assessment of PedCare according to Content Validity Index and binomial test, Fortaleza, Ceará, Brazil, 2018

\begin{tabular}{|c|c|c|}
\hline Items & CVlia $^{a}$ & $\boldsymbol{p}^{\mathbf{b}}$ \\
\hline Objectives and contente & 0.95 & \\
\hline 1) The newsroom is compatible with the public of interest and meets the needs of different groups & 0.93 & 0.175 \\
\hline 2) Information/content is suitable for guidance regarding the importance of self-care with feet & 1.00 & 0.226 \\
\hline 3) May promote behavioral changes in relation to self-care with feet & 0.96 & 0.571 \\
\hline 4) Content and image are motivating and encourage you to continue browsing the app & 0.93 & 0.429 \\
\hline 5) Content meets the needs of people with diabetes and foot at risk & 0.96 & 0.571 \\
\hline 6) It is possible to be scientifically disseminated on the theme of DM & 0.96 & 0.429 \\
\hline Structure and functionality & 0.91 & \\
\hline 7) The application provides foot care guidelines & 1.00 & 0.226 \\
\hline 8) The messages are displayed in an objective and clear way & 0.93 & 0.175 \\
\hline 9) The displayed content is scientific & 0.96 & 0.571 \\
\hline 10) There is a consistent follow-up of the matter & 0.93 & 0.429 \\
\hline 11) The content is appropriate for the public of interest & 0.98 & 0.175 \\
\hline 12) The text has good concordance and spelling & 0.89 & 0.000 \\
\hline 13) The literary style used is in accordance with the public of interest & 0.86 & 0.000 \\
\hline 14) Illustrations (images and GIFS) are convincing and in adequate quantity & 0.82 & 0.000 \\
\hline 15) The number of screens (screens) is satisfactory & 0.86 & 0.014 \\
\hline 16) The structure of the title, subtitle and topics are appropriate & 0.93 & 0.571 \\
\hline Relevance & 0.99 & \\
\hline 17) Content expresses evident issues & 1.00 & 0.226 \\
\hline 18) The application proposes improved proficiency and encourages foot care & 1.00 & 0.226 \\
\hline 19) The application brings content for the prevention of diabetic foot & 0.96 & 0.571 \\
\hline 20) Can be employed by a health professional during health education & 1.00 & 0.554 \\
\hline Total CVI & 0.95 & \\
\hline
\end{tabular}

Note: $a$-Content Validation Index for items; $b$ - binomial test.

Table 2 - Distribution of responses from the Suitability Assessment of Materials, Fortaleza, Ceará, Brazil, 2018

Domains

Punctuation Superior Adequate

\section{Content}

The goal is clear

The theme addresses the way to behave

The subject is related to the objective

The material highlights key issues

Literacy requirement

Degree of reading

Employs the newsroom voice writing

Employs everyday language

Presents previous circumstances before new ideas

The learning process is favored by items

04

lustration

The drawings express the objective

Shape of the drawings

The graphic resources are relevant

The resources employed are self-explanatory

Resources have explanatory words

$07 \quad 03$

$08 \quad 02$

ayout and presentation

Layout aspect

Size and quality of the spelling

Use of subtitles

earning stimulation/motivation Interactive

The teachings are exemplified

Motivation and self-efficacy

Cultural fit

Similarity between vocabulary and experience

$\begin{array}{lc}07 & 03 \\ 07 & 03 \\ 10 & - \\ 09 & 01 \\ 08 & 02 \\ & \\ 08 & 02 \\ 10 & - \\ 08 & - \\ & \\ 08 & 02 \\ 10 & - \\ 10 & - \\ & \\ 09 & 01 \\ 08 & 02\end{array}$


Table 3 - Validation by target audience, Fortaleza, Ceará, Brazil, 2018

\begin{tabular}{|c|c|c|}
\hline Domains & $f$ & $\%$ \\
\hline \multicolumn{3}{|c|}{ Organization } \\
\hline \multicolumn{3}{|c|}{ Did the app pique your interest? } \\
\hline Yes & 14 & 93.3 \\
\hline Partly & 01 & 6.7 \\
\hline \multicolumn{3}{|c|}{ Is the succession of ideas adequate? } \\
\hline Yes & 15 & 100 \\
\hline \multicolumn{3}{|c|}{ Is the application well organized? } \\
\hline Yes & 15 & 100 \\
\hline \multicolumn{3}{|c|}{ Writing style } \\
\hline \multicolumn{3}{|c|}{ Level of understanding of prayer: } \\
\hline Easy to understand & 14 & 93.3 \\
\hline Difficult to understand & 01 & 6.7 \\
\hline \multicolumn{3}{|l|}{ Written content is: } \\
\hline Easy & 15 & 100 \\
\hline \multicolumn{3}{|l|}{ The wording is: } \\
\hline Attractive & 15 & 100 \\
\hline \multicolumn{3}{|l|}{ Appearance } \\
\hline \multicolumn{3}{|l|}{ The drawings are: } \\
\hline Easy to understand & 15 & 100 \\
\hline \multicolumn{3}{|c|}{ Do the drawings complement the writing? } \\
\hline Yes & 15 & 100 \\
\hline \multicolumn{3}{|c|}{ Do the pages or sections appear organized? } \\
\hline Yes & 15 & 100 \\
\hline \multicolumn{3}{|l|}{ Motivation } \\
\hline \multicolumn{3}{|c|}{ Will anyone with diabetes who use the app understand? } \\
\hline Yes & 14 & 93.3 \\
\hline No & 01 & 6.7 \\
\hline \multicolumn{3}{|c|}{ Did you feel motivated to use the APP until the end? } \\
\hline Yes & 14 & 93.3 \\
\hline I do not know & 01 & 6.7 \\
\hline \multicolumn{3}{|c|}{ Does the application include essential foot care content for people with diabetes? } \\
\hline Yes & 14 & 93.3 \\
\hline \multicolumn{3}{|c|}{ Did the app encourage me to take care of my feet? } \\
\hline Yes & 15 & 100 \\
\hline
\end{tabular}

There are a multitude of APPs aimed at the public with diabetes; however, those who seek to promote self-care are restricted to basic functions (registration, representation and data delivery). In contrast, advanced features (features that require operating systems to perform tasks on devices) are implemented in small amounts $^{(6,17)}$.

PedCare is a technological innovation in healthcare, as it is an APP based on end users' needs (target audience) and scientific recommendations. The user-centered method establishes participation/collaboration between users and designers/researchers in the design phase for the development of computerized systems ${ }^{(18)}$.

Moreover, the APP added basic and advanced operational functions to enable patients to have an innovative final product. In this way, the alarm was adapted so that it would sound daily and according to risk stratification so that end users (people with diabetes and foot at risk) would seek professional care; shape video with exercises to improve the circulation of lower limbs by GIFS, as they have lower density; the focus and scope of the APP and convergence for the most varied groups of people with different literacy skills; verify usability through tests and clinical validation; provide space to publicize events in the area and physical and electronic addresses of class entities.

The validation process concerns the measure of making it valid. Thus, content validation makes it possible to assign value to a construct $^{(19)}$. Validating the product by judges and by end users and making it available in different mobile operating systems and with free download allow to obtain better positioning in the market and competitive advantage, increasing the number of users, and, consequently, of spreading and usability of the APP, favoring behavior change.

Concerning content validation by nurse judges, the selection of experts from different regions allows adapting the instrument built to the country's context as a whole, considering the cultural diversity of Brazil's continental dimensions of Brazil, which cannot be overlooked ${ }^{(20)}$. CVI and Cronbach's alpha values were satisfactory and guaranteed the validity and reliability of the developed technology.

Eight nurses participated in the validation of the APP Cuidar Tech "Exame dos Pés", aimed at assessing and stratifying the risk of people with diabetes. The group of judges identified the APP as functional, reliable, adequate, and efficient ${ }^{(21)}$.

In validation by ICT judges, PedCare was considered adequate in terms of content, literacy requirement, illustrations, layout and presentation, encouragement/motivation of learning and cultural adequacy, stating that its functions and design contributed to the perception of the messages contained. Using judges in this area allows specific heuristic dimensions for mobile devices: 1) identify the human/device interaction; 2) physical interaction and ergonomics; 3 ) readability and layout ${ }^{(21)}$.

The target audience validated PedCare by analyzing organization, writing style, appearance, and motivation. This step enabled verifying the understanding of the content and its subsequent 
adaptation to the educational and cultural level of the assessed population, representing a link between the empirical and theoretical correspondence of the application.

Images are important in any educational material because they are persuasive, they facilitate the understanding and memorization of information by the vast majority of people, in addition to making the material less tiring to read $^{(12)}$. It is essential that images are positioned in line with text.

PedCare was considered useful and easy to understand, portraying the reality experienced by patients, in addition to holding patients' attention and making them motivated to use. Motivation is one of the main determinants of success, quality of learning, usability of the device and behavior change ${ }^{(22)}$.

The creation and validation of technologies are fundamental and complex step, that require pedagogical attitudes and an appropriate method. If there is no validation process, there is a risk of making inappropriate material and without an educational objective ${ }^{(23)}$. The comments of judges and the target audience were satisfactory and praised PedCare, demonstrating its suitability.

It is reiterated that under no circumstances does the use of PedCare replace clinical nursing care in person, as it is a complex and multidimensional phenomenon; people with diabetes and foot at risk need interventions that raise awareness when engaging in therapy, in order to and feel encouraged not to abandon treatment.

\section{Study limitations}

A limiting factor in this study was the impossibility of using some resources (videos, data recording and use of resources for assistive technology) pointed out by the groups of judges and by the target audience at the expense of technology building burden.

\section{Contributions to nursing, health, and public policy}

PedCare is an innovative educational technology for promoting adherence to self-care with feet and learning with contextualized, reliable and accessible information, to be incorporated into the routine of people with diabetes and at-risk feet. It is expected that its free availability on Android and iOS platforms can contribute to favoring self-care promotion, preventing complications and, consequently, more serious cases, such as hospitalization and limb amputation by end users.

\section{CONCLUSION}

Building and validating a technological innovation in the form of a multimedia APP on a mobile platform called PedCare followed a rigorous method in its design, providing an assessment by professionals specialized in clinical care for people with diabetes and at-risk feet, experience professional in ICT and target audience, ensuring a product with relevant information, through simple and accessible language, as well as clear, objective and attractive figures and animations for the target audience (end-users).

\section{FUNDING}

Coordination for the Improvement of Higher Education Personnel (CAPES - Coordenação de Aperfeiçoamento de Pessoal de Nível Superior).

\section{REFERENCES}

1. Mirzaei M, Rahmaninan M, Mirzaei M, Nadjarzadeh A, Tafti AAD. Epidemiology of diabetes mellitus, pre-diabetes, undiagnosed and uncontrolled diabetes in Central Iran: results from yazd health study. BMC Public Health. 2020;20(166):1-9. https://doi.org/10.1186/ s12889-020-8267-y

2. Sarno F, Bittencourt CAG, Oliveira SA. Profile of patients with hypertension and/or diabetes mellitus from primary healthcare units. Einstein. 2020;18:1-6. https://doi.org/: 10.31744/einstein_journal/2020ao4483

3. International Diabetes Federation. IDF Diabetes Atlas [Internet]. 9th ed. Brussels (BE): International Diabetes Federation; 2019 [cited 2020 Mar 20]. Available from: www.diabetesatlas.org

4. Flor LS, Campos MR. Prevalência de diabetes mellitus e fatores associados na população adulta brasileira: evidências de um inquérito de base populacional. Rev Bras Epidemiol. 2017;20(1):16-29. https://doi.org/10.1590/1980-5497201700010002

5. Eleutério TT, Pereira EJ, Farias PKS, Hott KPS, Paula FMT, Martins AMEBL. Elaboration and verification of the validity and reliability of a nutrition literacy instrument among people with diabetes. Cad Saúde Colet. 2018;26(3):298-307. https://doi. org/10.1590/1414-462X201800030028

6. Rongzi SR, Sarkar S, Martin BS. Digital health technology and mobile devices for the management of diabetes mellitus: state of the art. Diabetologia. 2019;62(6):877-87. https://doi.org/10.1007/s00125-019-4864-7

7. Apelqvist J. The diabetic foot syndrome today: a pandemic uprise. In: Piaggesi A, Apelqvist J. The Diabetic Foot Syndrome. Basel: Karger Publishers; 2018. p. 1-18. https://doi.org/10.1159/000480040

8. Fleming GA, Petrie JR, Bergenstal RM, Holl RW, Peters AL, Heinemann L. Diabetes Digital App Technology: benefits, challenges, and recommendations. A Consensus Report by the European Association for the Study of Diabetes (EASD) and the American Diabetes Association (ADA) Diabetes Technology Working Group. Diabetologia. 2020;63(2):229-41. https://doi.org/10.1007/s00125-019-05034-1

9. Milne-Ives M, Lam C, Cock C, Van Velthoven MH, Meinert E. Mobile apps for health behavior change in physical activity, diet, drug and alcohol use, and mental health: systematic review. JMIR Mhealth Uhealth, 2020;18;8(3):1-16. https://doi.org/10.2196/17046 
10. Sousa CS, Turrini RNT, Poveda VB. Translation and adaptation of the instrument "suitability assessment of materials" (sam) into portuguese. Rev Enferm UFPE. 2015;9(5):7854-761. https://doi.org/10.5205/reuol.6121-57155-1-ED.0905201515

11. Marques ADB. Aplicativo multimídia em plataforma móvel para a promoção de cuidado com os pés de pessoas com diabetes: ensaio clínico controlado randomizado [Tese] [Internet]. Fortaleza: Programa de Pós-Graduação Cuidados Clínicos em Enfermagem e Saúde, Universidade Estadual do Ceará; 2018[cited 2020 Mar 20]. 218. Available from: http://200.129.22.236/cmacclis/dmdocuments/ANTONIODEAN.pdf

12. Galdino YLS, Moreira TMM, Marques ADB, Silva FAA. Validation of a booklet on self-care with the diabetic foot. Rev Bras Enferm. 2019;72(2):780-7. https://doi.org/10.1590/0034-7167-2017-0900

13. Polit DF, Beck CT. Fundamentos de Pesquisa em Enfermagem: avaliação de evidências para as práticas de Enfermagem. Brasil: Artmed; 2018.

14. Taber KS. The use of Cronbach's alpha when developing and reporting research instruments in science education. Res Sci Educ. 2018;48(6):1273-96. https://doi.org/10.1007/s11165-016-9602-2

15. Doupis J, Festas G, Tsilivigos C, Efthymiou V, Kokkinos A. Smartphone-based technology in diabetes management. Diabetes Ther. 2020;11(3):607-619. https://doi.org/10.1007/s13300-020-00768-3

16. Silva AMA, Mascarenhas VH, Araújo SNM, Machado RS, Santos AMR, Andrade EMLR. Mobile Technologies in the nursing area. Rev Bras Enferm. 2018;71(5):2570-8. https://doi.org/10.1590/0034-7167-2017-0513

17. Salari R, Kalhori SRN, Fatehi F, Ghazisaeedi M, Nazar Mahin M. Determining minimum set of features for diabetes mobile apps. J Diabetes Metab Disord. 2019:18(3):333-40. https://doi.org/10.1007/s40200-019-00417-y

18. Marques ADB, Moreira TMM, Jorge TV, Rabelo SMS, Carvalho REFL, Felipe GF. Usability of a mobile application on diabetic foot self-care. Rev Bras Enferm. 2020;73(4):e20180862. https://doi.org/10.1590/0034-7167-2018-0862

19. Santiago JCS, Moreira TMM. Booklet content validation on excess weight for adults with hypertension. Rev Bras Enferm. 2019;72(1):95-101. https://doi.org/10.1590/0034-7167-2018-0105

20. Borges JWP, Moreira TMM, Andrade DF. Nursing care interpersonal relationship questionnaire: elaboration and validation. Rev Latino-Am Enfermagem. 2017;25:e2962. https://doi.org/10.1590/1518-8345.2128.2962

21. Vêscovi SJ, Primo CC, Sant'Anna HC, Bringuete ME, Rohr RV, Prado TN, et al. Aplicativo móvel para avaliação dos pés de pessoas com diabetes mellitus. Acta Paul Enferm. 2017;30(6):607-13. https://doi.org/10.1590/1982-0194201700087

22. Yen AMNL. The influence of self-regulation processes on metacognition in a virtual learning environment. Education Stud. 2018;46(1):1-17. https://doi.org/10.1080/03055698.2018.1516628

23. Savalor PTCO, Mariz CMS, Vitor AF, Ferreira Jr MA, Fernandes MID, Martins JCA, et al. Validation of virtual learning object to support the teaching of nursing care systematization. Rev Bras Enferm. 2018;71(1):11-9. https://doi.org/10.1590/0034-7167-2016-0537 